\title{
Study on the Core of Enterprise Management in the Network Times XIAN HaiYun ${ }^{1, \text { a }}$ \\ ${ }^{1}$ Tianjin university, Tianjin 300072,China \\ axianhaiyun@126.com
}

Keywords: core, enterprise management, the network times

\begin{abstract}
In the 21st century, with the economic globalization and the global network, the enterprise will be facing the global market more competitively. The traditional enterprise management science theory and practice can not meet the requirements of the network times. Therefore, it is imperative to reform and innovate the enterprise management, and network becomes a kind of unprecedented scientific measure, which directly causes not only a new revolution of new technology and a revolution of the new productive forces and production relations, but also a management revolution with far-reaching significance.
\end{abstract}

\section{The opportunities of enterprise management in the Internet times}

With the advent of the era of network, the popularization and application of information technology, information product, and information service bring up a large number of network enterprises. At the same time, it makes a lot of opportunities for the traditional enterprise in terms of production technology and business process improvement, the enterprise information management and network marketing. Detail information is written in the following:

1) It can better meet the personalized needs of customers.

In the Internet age, the enterprise can establish direct contact with customers via the Internet: interactive communication with customers, knowing advice and opinions from consumers on products and services, understanding customer's preferences, location distribution, so as to improve the business process, improve marketing methods, improve the management level from direct access to customer information of products and services, and finally meet the personalized needs of customers and make benefits.

2) It can reduce the enterprise cost.

Enterprise can purchase raw materials through online bidding and tendering with the Internet to complete the order, so that saving transaction cost, manage the customer

3) It can reduce the enterprise inventory.

The root cause of inventory is blocked information. With the coming of the network era, it could pass the market information timely to the enterprise for decision. Even if the inventory is become larger and larger, warehouse become a transit point rather than for stock. The requirements of enterprise can immediately pass to supplier to supplement timely with the Internet, so as to realize zero inventory management.

4) It can make the enterprise a better implement the strategy of cooperative competition.

Enterprises can realize remote management and the remote resource sharing based on the Internet, in order to achieve a project recombined a virtual enterprise by a few enterprises or parts of the enterprises and maximize the integration of enterprise resources through information sharing mode of collaborative work in parallel.

5) It can improve the ability to acquire knowledge and apply knowledge for enterprises.

The development of the Internet makes a revolutionary change to the knowledge creation, storage, produces, learn and use.

\section{The challenges of enterprise management in the Internet times}

In the Network era, opportunities and challenges both exist. Enterprises are faced with severe challenges in the following aspects: 
1) Enterprises face increasingly fierce competition. The development of the Internet promotes the economic globalization, expands the market area, and makes more enterprises join the competition. Consumers can choose the supplier in the larger ranges and grasp the market information more and more conveniently and accurately. Companies locking customers becomes more and more difficult, and enterprises are in danger of losing their market share.

2) The customer's power is greatly enhanced. The development of the Internet provides consumers with better access to information about products and the seller of the channels. Customers get to know and choose enterprise providing products or services through the Internet, and the information symmetry is higher and higher.

3) The enterprise's overall profitability will go down. The application of the Internet reduces the requirement for sales force and distribution channels, reduces industry barriers for potential competitors to get into the market making more enterprises provide consumers with products and services.

4) Critical success factors for enterprises will change. Network era completely changes key success factors for the traditional enterprise, and causes success of the enterprise difficult to keep competitive advantage.

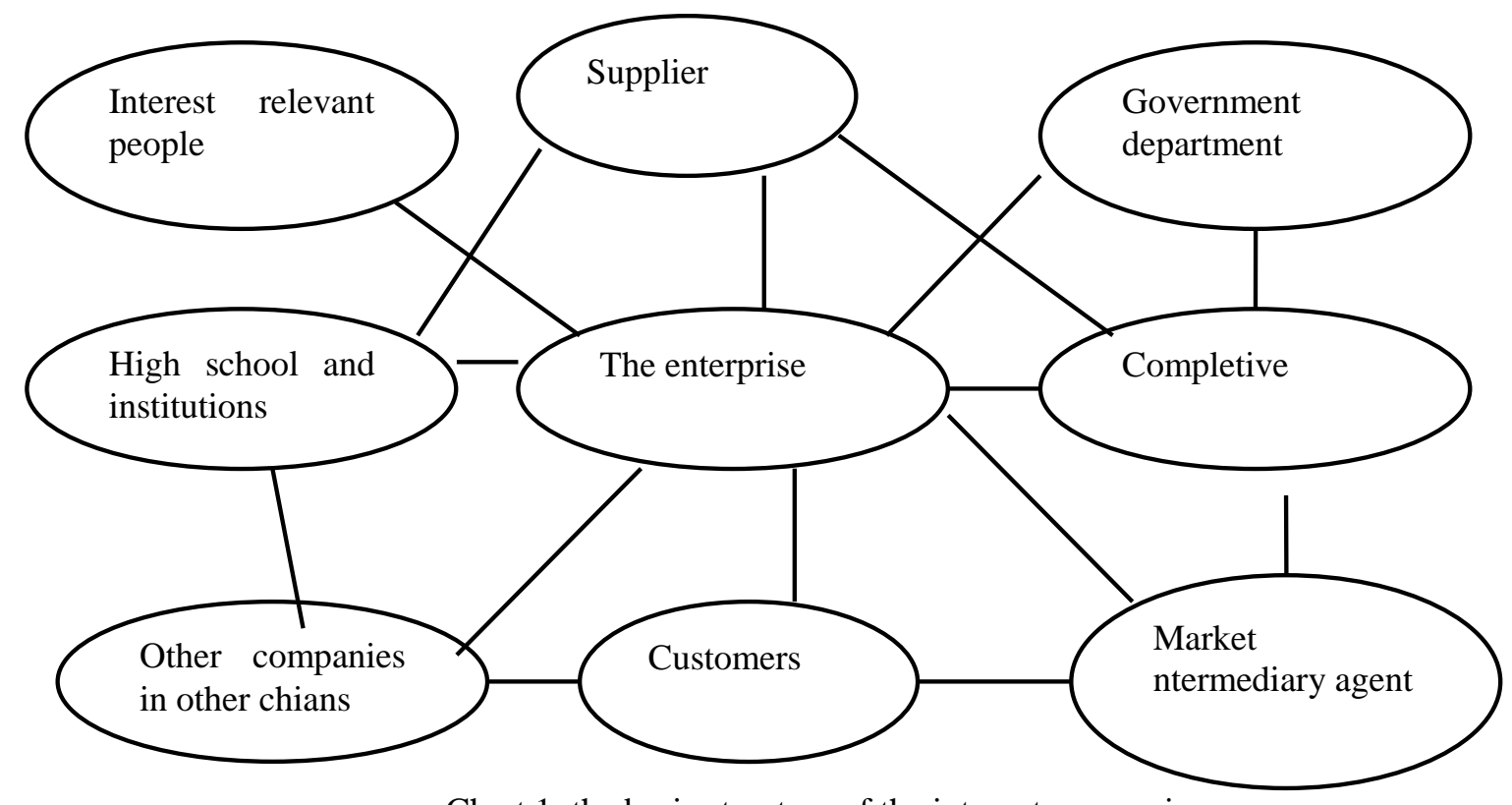

Chart 1: the basic structure of the internet economic

\section{The core of the enterprise}

Enterprise core competence refers to acquisition, configuration and resources forming and maintaining competitive advantage. It includes two aspects: one is the ability that the enterprise obtains all kinds of resources or technologies and transform to skills and products of the enterprise; the second is the ability that the enterprise organizes production elements to product and makes each link of the enterprise in the coordination of efficient operation.

Core competence is the comprehensive ability based on knowledge and technology, which is to support the enterprise survival and get steady development and initiative advantage in the in the competitive environment for a long time.

Core competence mainly includes core technical capabilities, organization and coordination ability, outside influence and potential competition ability, among which the outside impact of the enterprises is the enterprise overall strength concentrated external performance, is the competition ability the enterprise exhibiting to the market of its products, brand and image. The direct performance of products market competition among enterprises is confrontation, target market competition, therefore, the external competitiveness is the most direct and the most useful weapon to obtain the market share and beat the competitors. Enterprise competitiveness is future development potential of the enterprise, and itself has very strong diffusibility, which plays a 
decisive influence on the development of enterprises. The essential connotation of cultivating core competence is to enable enterprises to create higher irreplaceable values, products, services and culture than their competitors.

Enterprise having certain advantages on a particular aspect or a product doesn't mean that the enterprise must have strong core competence. Only this kind of product and technology make computers cannot surpass the company in a longer period of time and be able to maintain this kind of condition, which is the embodiment of the real core competence. Therefore the enterprise strength or competitive advantage is not the product, but the core technical competence of the company.

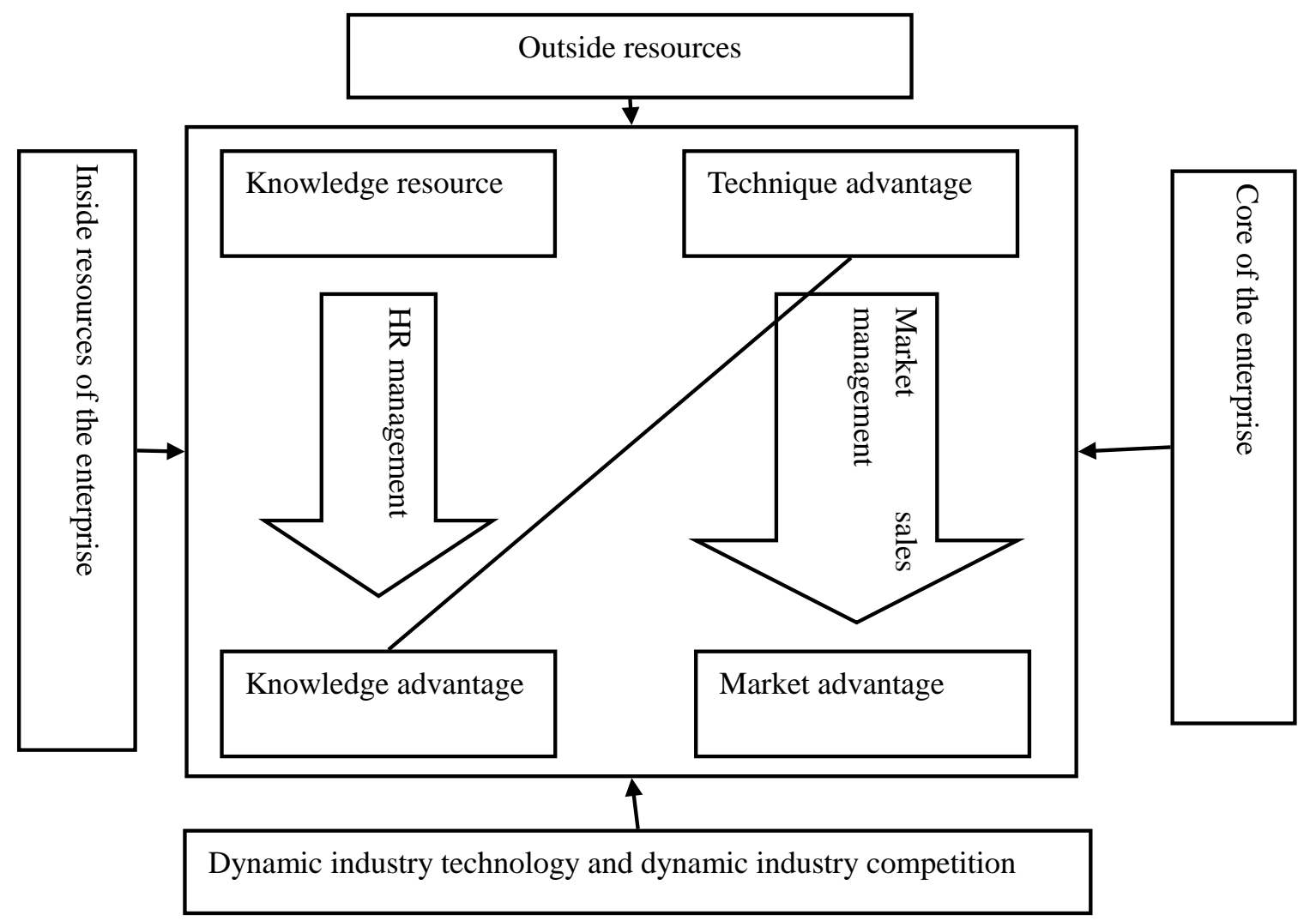

Chart 2: the process of the management of the core competence of the enterprise

\section{The elements of the core competence of the enterprise}

Management means that the managers can organize on rational allocation the limited resources in order to realize the dynamic process of organizational goals through a series of management functions. Organizing all kinds of resources is the core of the management.

1) Research and development capabilities

Research and development (Research and development, short as R and D), according to the definition of the United Nations educational, scientific and cultural organization, refers to systematic creation activities in order to increase the amount of knowledge, and use this knowledge to create new applications. It includes basic research, applied research and technology development.

2) Innovative ability

The so-called innovation is to integrate talents, capital and other resources according to the changes of the market and social on the basis of the original conditions and continuously create new product research and development production and effective organization, create and adapt to the market to realize the process of enterprise target, which includes technological innovation, product and process innovation and management innovation. To obtain the core competence, enterprise must accurately grasp the world science and technology and market development, formulate corresponding innovation strategy, and make the technological innovation, management innovation, product innovation and coordination. Table one is about the different ways to knowledge 
management.

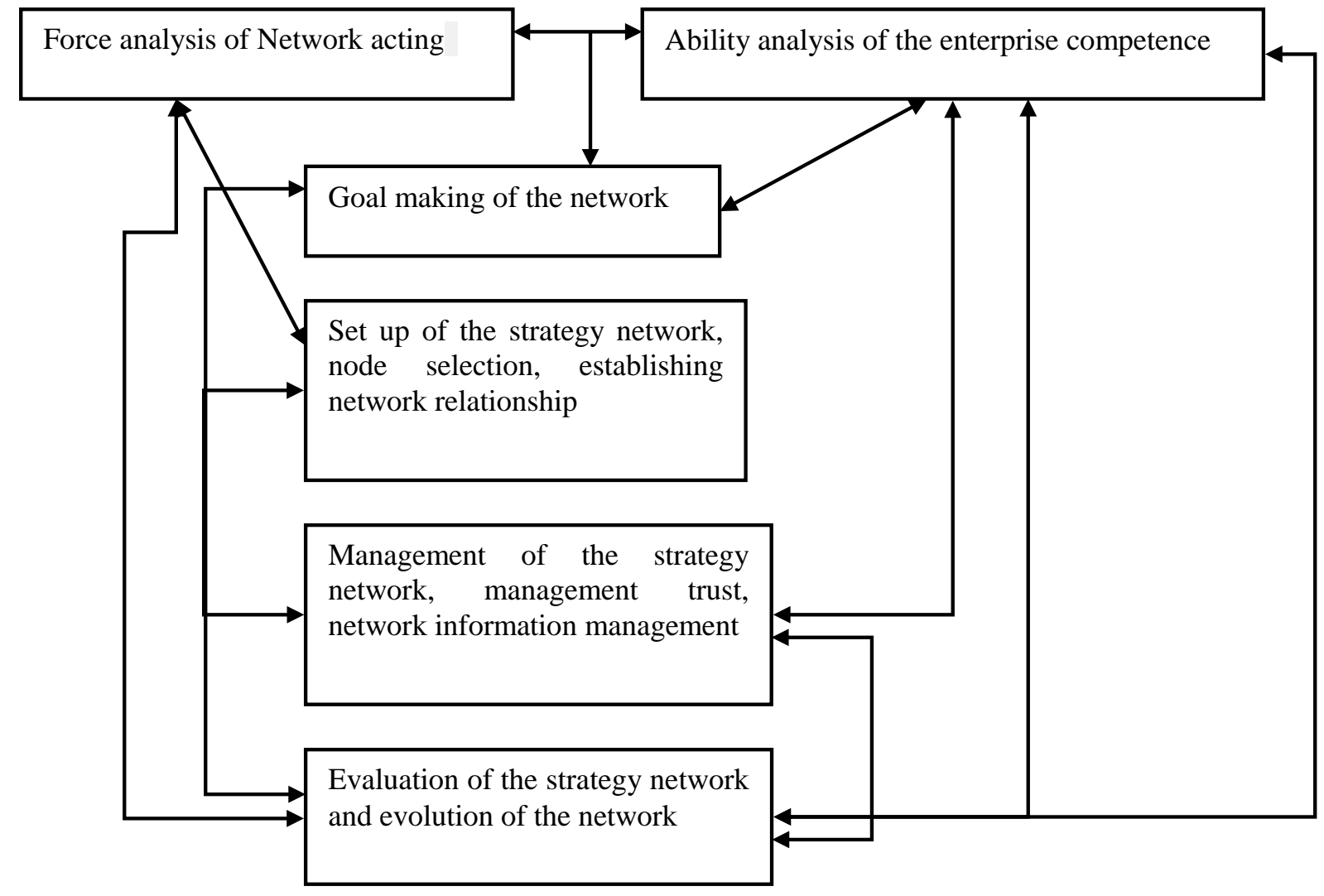

Chart 3: the overall framework of the network management based on core competence Table 1: the different ways to the knowledge management

\begin{tabular}{|l|l|l|l|l|}
\hline \multirow{2}{*}{} & \multicolumn{4}{|l|}{ knowledge management } \\
\cline { 2 - 5 } & Objects & Routes & Personalities & strategies \\
\hline $\begin{array}{l}\text { Encoded } \\
\text { knowledge }\end{array}$ & Knowledge & Organization & Psychological & HR \\
manecialist & management \\
\hline $\begin{array}{l}\text { Coded } \\
\text { knowledge }\end{array}$ & database & $\begin{array}{l}\text { Network } \\
\text { management }\end{array}$ & $\begin{array}{l}\text { Computer } \\
\text { specialist }\end{array}$ & $\begin{array}{l}\text { Information } \\
\text { management }\end{array}$ \\
\hline
\end{tabular}

3) Transform the product or technology and invention achievement into real productivity

Only to convert the innovation consciousness and technological achievements into practical work plan or products can improve the efficiency and effectiveness, innovation and \& RD. Transformation ability has a lot to do with the enterprise's technology ability, management ability. The process of innovation is also the process of, the process of transformation not only needs further innovation, but also needs the feasible methods and steps. Only transform the innovation into actual benefit can be the true sense of innovation.

\section{Summary}

The key to improve enterprise's core competence is innovation. Innovation is the lifeblood of enterprise survival and development. Innovation is the change of the production function or a new combination of production elements and production conditions. Innovation can be improved from the following four aspects: improving the ability of resource integration, improving the enterprise research and development ability, extending the enterprise marketing ability, activating the source power enterprises. To promote the core competence, enterprise must get innovation running through the whole process of enterprise management. 


\section{References}

[1] Lau, lawrence, Qian, Yingyi, Roland, G. Pareto- improving economic reforms through dualtrack liberalization [ J] .Economic letters. 1997( 55) : 285- 292.

[2] Hong Yinxing, Ge Yong, Local government function in the economic system transition [J]. Journal of economic studies, 1996, (5) : 22 -28.

[3] Xia Dawei, economic study of the enterprise facing the new economic times[M].Shanghai: Shanghai university of finance and economics press,2001.

[4] Hu Yanting, China network ecological economic development report from 2000 to 2001[R]. Beijign: Social Sciences Academic Press, 2001.

[5] Liu Guangqi, Management mode[M]. Beijing: Enerprise management press,1997. 